\begin{tabular}{|l|l|}
\hline 2. To: (Receiving Organization) & 3. From: coriginating Organization) \\
TWRS Technica] Operations & TWRS Technical Operations \\
\hline 5. Proj./Prog./Dept./Div.: & $\begin{array}{l}\text { 6. Design Authority/ Design Agent/Cog } \\
\text { Engr.: } \\
\text { 702AZ/TWRS }\end{array}$ \\
\hline WD Winkelman
\end{tabular}

8. originator Remarks:

Original release for testing of Year 2000 compliance of equipment in 702AZ Ventilation System.

$$
\text { USQ- TF- } 9 B-0707
$$

11. Receiver Remarks: 11A. Design Baseline Document? [] Yes [X] No

4. Related EDT No.:
NA
7. Purchase Order No.:
NA

9. Equip./Component No.: Micon/Chiller/UPS/VSD

10. System/Bldg./Facility: 241-AZ-702

12. Major Assm. Dwg. No.:

NA

13. Permit/Permit Application No.: NA

14. Required Response Date: $7 / 20 / 98$

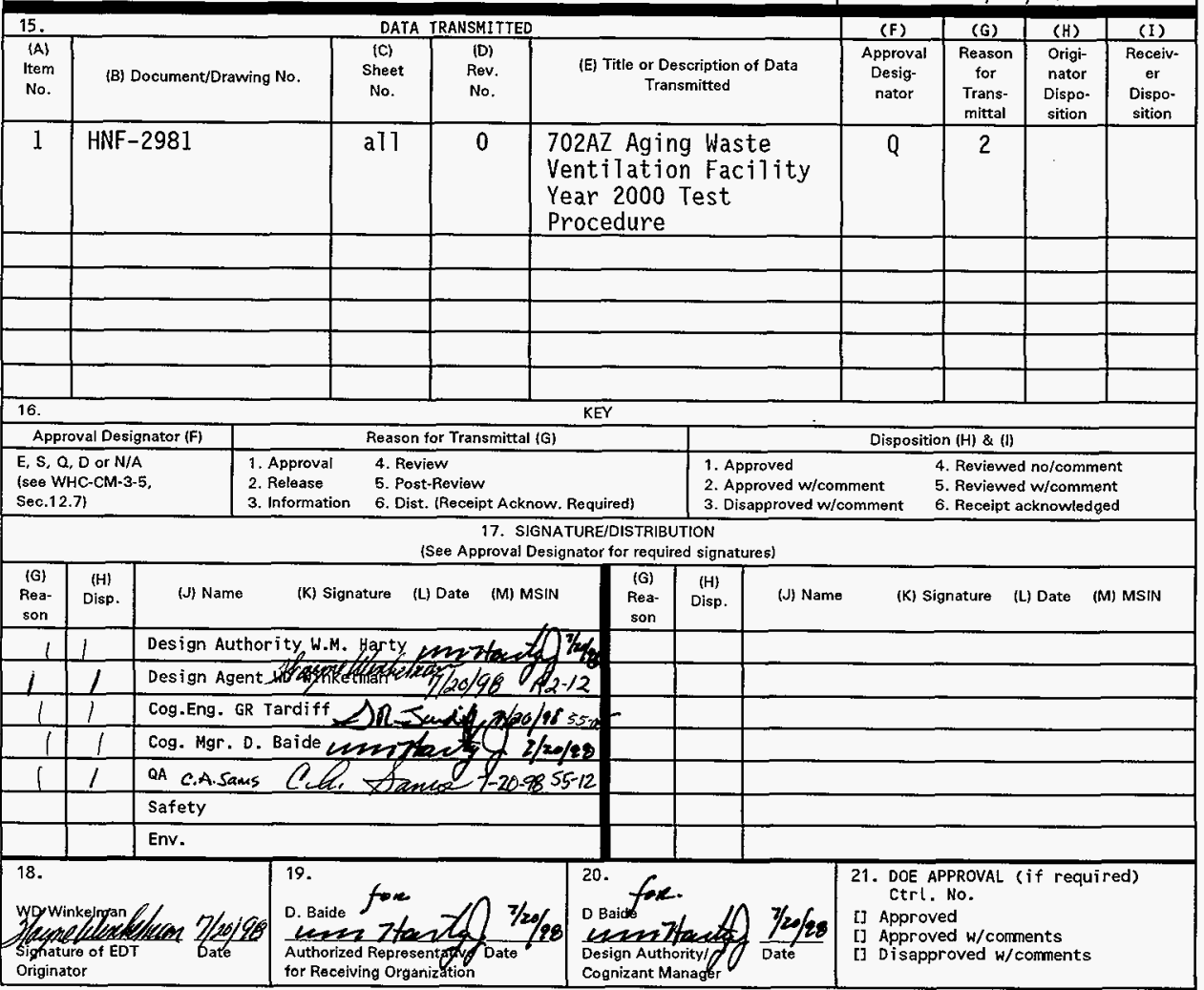


HNF-2981, Rev. 0

\title{
702AZ Aging Waste Ventilation Facility Year 2000 Test Procedure
}

\author{
W. D. Winkeiman \\ Lockheed Martin Hanford Company, Richland, WA 99352 \\ U.S. Department of Energy Contract DE-AC06-96RL13200
}

EDT/ECN: EDT-625055

Org Code: 7 A110

B\&R Code: EW3130010

UC: 2030

Charge Code: E57230

Total Pages:

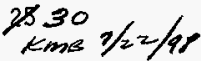

Key Words: Year 2000, Test Procedure, MICON, Project $W-030,241-A Z-702$ Ventilation Facility

Abstract: This document describes the procedure to test the Year 2000 susceptable components for compliance. It includes testing procedures for the Micon DCS, Cutler Hammer VSD, Durham Bush Chiller, IHD UPS and other ventilation facility equipment.

Micon is a trademark of Powell Industry Inc.

SPARCStation is a trademark of Sun Systems Inc.

ASVIEW is a trademark of Powel Industry Inc.

TRADEMARK DISCLAIMER. Reference herein to any specific commercial product, process, or service by trade name, trademark, manufacturer, or otherwise, does not necessarily constitute or imply its endorsement, recommendation, or favoring by the United states Government or any agency thereof or $i$ ts contractors or subcontractors.

Printed in the United States of America. To obtain copies of this document, contact: Document Control Services, P.0. Box 950, Mailstop H6-08, Richland WA 99352, Phone (509) 372-2420;

Fax (509) 376-4989.
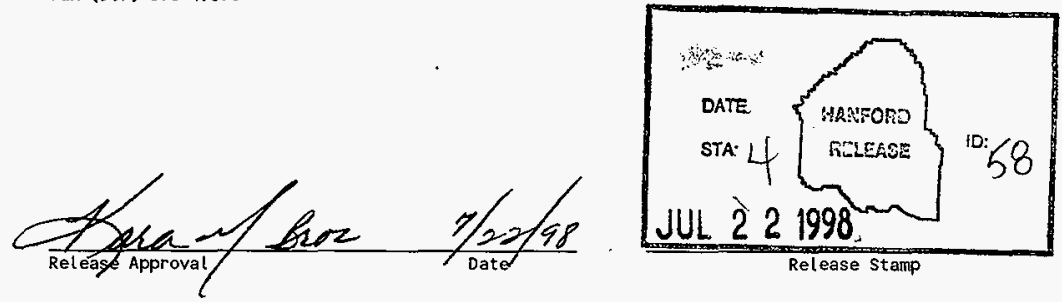
HNF-2981 Rev. 0

\title{
702AZ Aging Waste Ventilation Facility Year 2000 Test Procedure (Project W-030)
}

\author{
July 1998 \\ Issued by: \\ Lockheed Martin Hanford Corporation \\ for the \\ United States Department of Energy, Richland Operations Office \\ Richland, WA
}


HNF-2981 Rev. 0

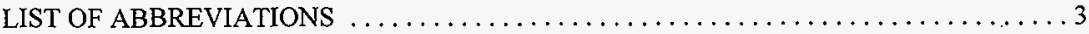

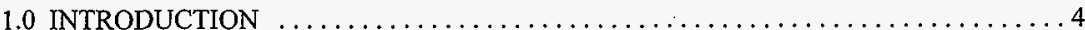

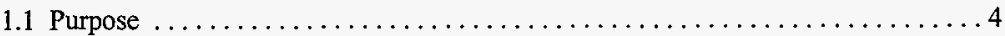

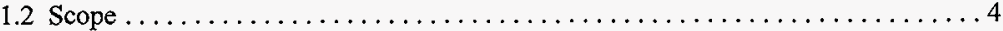

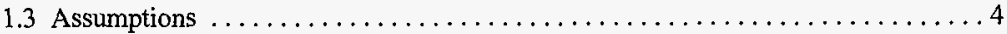

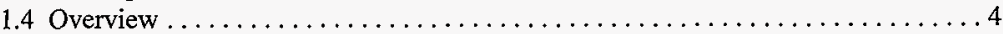

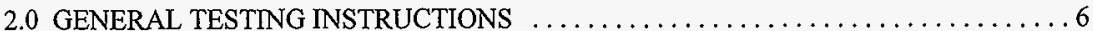

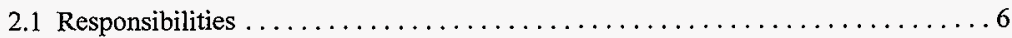

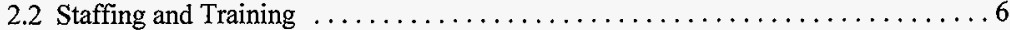

2.3 Logging Test Results. . . . . . . . . . . . . . . . . . . . . . . . . . . . 6

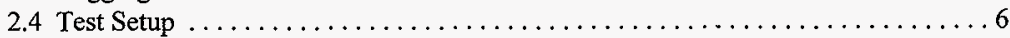

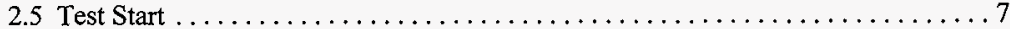

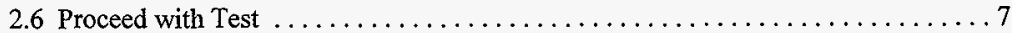

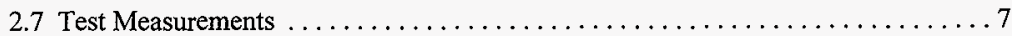

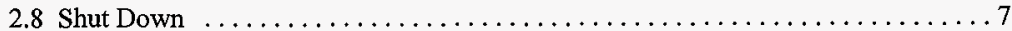

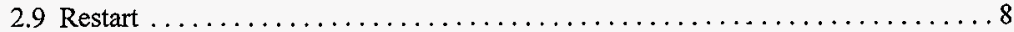

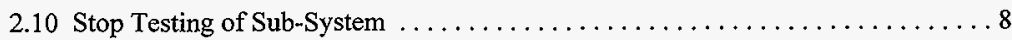

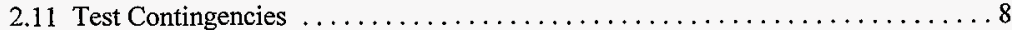

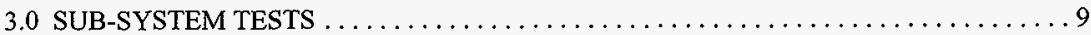

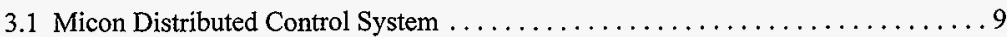

3.2 Fire Control Station Simplex Time Recording Co. Model 4100-8001 . . . . . . . 18

3.3 Control Room Air Conditioner DA Data Aire Inc. DTAU-0332 . . . . . . . 19

3.4 Primary Process Air Chiller Dunham Bush model ACDR-55-B . . . . . . . . . 20

3.5 Continuous Air Monitor Eberline model AMS-4 Software version $3.0 \ldots \ldots \ldots 22$

3.6 Variable Speed Drive Cutler Hammer Model AF95 ................ 24

3.7 Un-interruptable Power Supply International Power Machines Model IBP+10 . . 26

ATTACHMENT 1: 702AZ VENTLLATION FACILITY YEAR 2000 TEST CRITERIA _ . . 28

ATTACHMENT 2: TEST DISCREPANCY LOG SHEET $\quad \ldots \ldots \ldots \ldots \ldots \ldots 29$ 


\section{LIST OF ABBREVIATIONS}

Acceptance Test - Formal testing conducted to determine whether a system satisfies its acceptance criteria and to enable the customer to determine whether to accept the system (IEEE Std. 610.12-1990).

Engineering Workstation (EWS) - This Operator Control System(OCS) is designated as Master and is responsible for setting the system time to all OCS.

General Purpose LAN Interface (GPLI) - The interface between the dual data highway and either modems or OCS. An OCS connects to the Thinnet port. One or more modems connect to Terminal Block 2 with a three-wire connection.

Local Control Unit (LCU) - Houses a combination of RCM(Remote Control Module) controllers and $\mathrm{U} 32$ controllers.

Cognizant MCS (Micron Control Station)engineer - The engineer responsible for the 702AZcontrol system who is assigned the principal responsibility for the development of changes to existing computer software.

Operator Control Station (OCS) - The operator interface to the process that connects to the GPLI via ethernet port.

Remote Control Module (RCM) - The interface between the analog and/or discrete instrumentation and the control system, which is connected to the U32 via fieldbus. This device contains programming that it receives from the EWS.

U32 Controller (U32) - Provides and interface between RCMs and the rest of the control system. This device can contain programming that it receives from the EWS. 


\subsection{INTRODUCTION}

\subsection{Purpose}

This test procedure was developed to determine if the 702AZ Tank Ventilation Facility system is Year 2000 Compliant. The procedure provides detailed instructions for performing the operations necessary and documenting the results. This verification procedure will document that the $702 \mathrm{AZ}$ Facility Systems are year 2000 compliant. and will correctly meet the criteria established in this procedure.

\subsection{Scope}

The Aging Waste Facility (AWF) provides underground tank storage of high-level radioactive waste at the Hanford Site. The four tanks in the AWF require ventilation for confinement, cooling, and flammable gas mitigation. The scope of this document is limited to the 702AZ Tank Ventilation Facility (W-030 Project) equipment and interfaces of the AWF.

\subsection{Assumptions}

If no adverse symptoms are observed when the test is executed, it will be assumed that the system will operate successfully during the year 2000 changeover.

\subsection{Overview}

This document addresses testing of the vendor software for the 702AZ Ventilation facility equipment control systems. The system is comprised of many instruments, local system controllers and the MICON Measurement and Control System (MCS). An assessment was made of system equipment and although many of the system instruments have digital components, they are not aware of time or date and therefore not subject to the Year 2000 changeover issue. The system assessment identified eight subsystems of the $702 \mathrm{AZ}$ ventilation facility that require $\mathrm{Y} 2 \mathrm{~K}$ evaluation and testing. These sub-systems are: 
HNF-2981 Rev. 0

- The MICON DCS

- The Continuous Air Monitor (CAM)

- The primary process Chiller

- The fire alarm control system

- The diesel generator

- The Un-interruptible Power System's

- The Control Room HVAC.

- The primary fan Variable Speed Drive (VSD) control.

The preliminary assessment identified the diesel generator as being time and date aware, however further investigation has determined that it is not and will therefore not be tested. These systems (with the exception of the diesel generator) are time and date aware with provisions for inputting and display. However, in all cases, no system functions are initiated based on time or date. The time and date information is used for "STAMPING" process information with time and date information. These system all work independently and do not share their individual time and date information with the other systems. 


\subsection{GENERAL TESTING INSTRUCTIONS}

The following guidelines should be followed in the performance of testing of each of the 702AZ subsystems being checked for year 2000 operation.

\subsection{Responsibilities}

The cognizant MCS engineer is responsible for documenting, managing, designing, preparing the tests, and resolving test-related issues. Operations and maintenance personnel will assist in performing equipment configuration operations.

\subsection{Staffing and Training}

This procedure shall be managed and documented by engineering personnel experienced in the operation and maintenance of the equipment. Operational and maintenance personnel will be responsible for operation of equipment as required.

\subsection{Logging Test Results.}

The performance of each step of the test will be documented by initialing and indicating the time and date of completion. All test data will be incorporated into an acceptance test report and released as a supporting document in accordance with engineering procedures. Test data will include the signed procedure steps in this document, all test discrepancy log sheets (Attachment 2), and where possible, any test results which can be captured from screen displays or data files.

\subsection{Test Setup}

Before performing tests, consult with Operations Engineering personnel on duty to assure facility is properly configured to minimize potential impact. This may include configuration of process overrides and/or local operation of critical components. 


\subsection{Test Start}

Each test will begin by using the equipment interface to enter the desired date. The following dates will be tested on each of the facility sub-systems.

$\begin{array}{lll}\text { December } 31,1999,11: 55 \mathrm{pm} & \text { to } & \text { January 1, 2000, 12:05am } \\ \text { February } 28,2000,11: 55 \mathrm{pm} & \text { to } & \text { February 29, 2000, 12:05am } \\ \text { February } 29,2000,11: 55 \mathrm{pm} & \text { to } & \text { March 1, 2000, 12:05am } \\ \text { December } 30,2000,11: 55 \mathrm{pm} & \text { to } & \text { December 31, 2001, 12:05am } \\ \text { December } 31,2000,11: 55 \mathrm{pm} & \text { to } & \text { January 1, 2001, 12:05am } \\ \text { February } 28,2001,11: 55 \mathrm{pm} & \text { to } & \text { March 1, 2001, 12:05am }\end{array}$

\subsection{Proceed with Test}

Each sub-system will be allowed to operate through the assigned time frame. Typically this will be at least 10 minutes from the time of setting the test time.

\subsection{Test Measurements}

Each sub-system will be required to continue operations throughout the test. Each sub-systems handling of the date will be monitored and recorded for each date function. Anomalies will be recorded.

\subsection{Shut Down}

At the completion of each test sequence,(if appropriate as indicated in the individual test), the sub-system will be shut-down and restarted to determine if normal operations will continue upon a loss of power or system restart. Assure that the process is properly configured to allow a subsystem shutdown. 
HNF-2981 Rev. 0

\subsection{Restart}

After the successful completion of date test of interest, the procedure will be iterated on the next date of interest. If for some reason the tests do not proceed as planned, the sub-system should be reset and the test for that date should be started again from the beginning before going on to the next date.

\subsection{Stop Testing of Sub-System}

The current date will be reentered into the sub-system and the system will be monitored for a normal return to operations. Any data files generated during the testing phase should be removed from the system.

\subsection{Test Contingencies}

If for any reason the sub-system being tested fails during the test, every effort possible to return the sub-system to current date and operation should be made. Manufacturers documentation should be used as necessary to return the system to functionality.

If other portions of the Ventilation Facility fail during sub-system testing, at the discretion and need of the Operations Engineer on duty, return the sub-system to normal operation. Testing can continue at a later date as appropriate. 
HNF-2981 Rev. 0

\subsection{SUB-SYSTEM TESTS}

'The following tests should be performed individually on the listed equipment. No date information is shared between sub-systems and therefore no overall system test is required.

\subsection{Micon Distributed Control System}

The MICON distributed control system consists of the following components. The operator control station (OCS) is a Sun SPARC STATION 5 computer system. The OCS are interconnected on an Ethernet LAN and also interconnected to the Remote controllers on a separate token ring LAN. There are 33 remote computer controllers connected to the 4 OCS stations. See HNF-SD-WM-CSWD-071 for detailed information on the system organization. The OCS are running SunOS 4.1.4 as the computer operating system. Custom MICON interface software is referred to as ASView and is currently version 3.1.58a.

All features to be tested involve the time and date stamp that the OCS attaches to various displays, data, and files. The information recorded will be either the value of the date and time stamp or an affirmation that the clock correctly advanced to the proper date and time. In cases where appropriate, the directory listings and ASCII files containing file date and time stamps can be exported and printed as support information and included in the acceptance test report as required. 


\subsubsection{Startup and Prerequisite Conditions:}

\begin{tabular}{|c|c|c|}
\hline step & Prerequisite action & Initials and date \\
\hline 1 & $\begin{array}{l}\text { Create a revision file of current application files and release } \\
\text { versions. Use rev name "Y } 2 \mathrm{~K} \text { " and include in records. } \\
\text { Verify ASVIEWrM version_3.1.58a }\end{array}$ & \\
\hline 2 & $\begin{array}{l}\text { Move all (except current date and time) Historian and Message files } \\
\text { to storage directory. (For retrieval at end of testing.) }\end{array}$ & \\
\hline 3 & $\begin{array}{l}\text { Print the following files. } \\
\text { TPSI file-/home/Date/Tpsi/ W320.csv .. } \\
\text { Alarm history file -/home/Data/Message/Ahf??????.Txt } \\
\text { Message history file - /home/Data/Message/Mhf??????.Txt } \\
\text { Operator Action File - /home/Data/Message/Ohf?????.Txt } \\
\text { ASCII Historian file --- /home/Data/History/a_?????? (1 page) }\end{array}$ & \\
\hline 4 & Verify date and time are correct. & . \\
\hline 5 & Verify operation of pictorial historian & \\
\hline \multicolumn{3}{|c|}{ Verify System is operational and functioning properly: } \\
\hline 6 & Activate event & \\
\hline 7 & Acknowledge Alarm & \\
\hline 8 & Verify creation date and time stamp of event --Message History & \\
\hline 9 & Verify creation date and time stamp of event - Operator Action & \\
\hline 10 & Verify creation date and time of event - recent alarm display & \\
\hline 11 & Verify creation date and time of event - alarm history display & \\
\hline
\end{tabular}




\subsubsection{Test transition from December 31, 1999 11:55 PM to January 1, 2000 12:05 AM.}

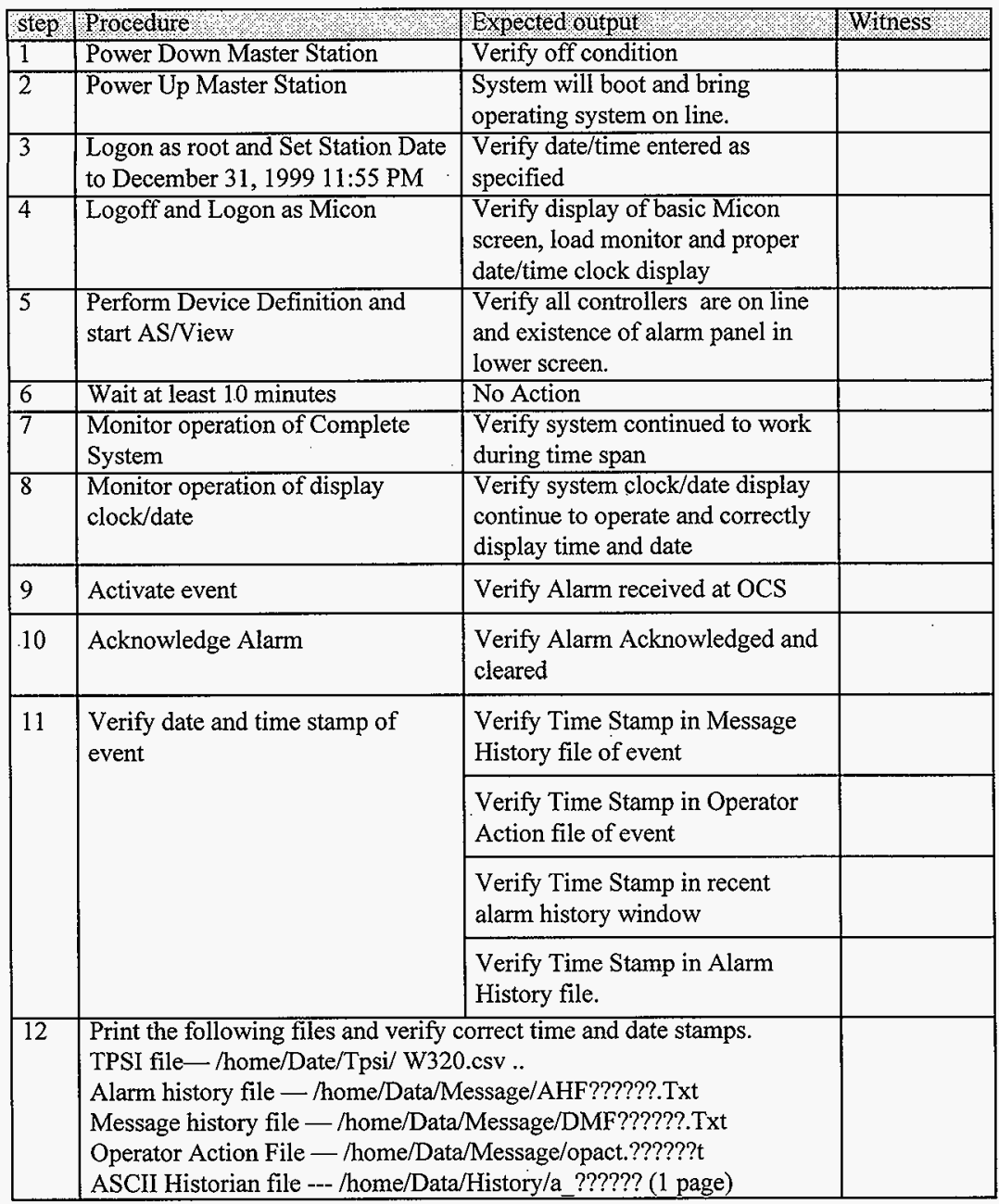


3.1.3 Test transition from February 28, 2000 11:55 PM to February 29, 2000 12:05 AM.

\begin{tabular}{|c|c|c|c|}
\hline steps. & Procedure & Expected output & Witness \\
\hline 1 & Power Down Master Station & Verify off condition & \\
\hline 2 & Power Up Master Station & $\begin{array}{l}\text { System will boot and bring } \\
\text { operating system on line. }\end{array}$ & \\
\hline 3 & $\begin{array}{l}\text { Logon as root and Set Station Date } \\
\text { to February } 28,200011: 55 \mathrm{PM}\end{array}$ & $\begin{array}{l}\text { Verify date/time entered as } \\
\text { specified }\end{array}$ & \\
\hline 4 & Logoff and Logon as Micon & $\begin{array}{l}\text { Verify display of basic Micon } \\
\text { screen, load monitor and proper } \\
\text { date/time clock display }\end{array}$ & \\
\hline 5 & $\begin{array}{l}\text { Perform Device Definition and } \\
\text { start AS/View }\end{array}$ & $\begin{array}{l}\text { Verify all controllers are on line } \\
\text { and existence of alarm panel in } \\
\text { lower screen. }\end{array}$ & \\
\hline 6 & Wait at least 10 minutes & No Action & \\
\hline 7 & $\begin{array}{l}\text { Monitor operation of Complete } \\
\text { System }\end{array}$ & $\begin{array}{l}\text { Verify system continued to work } \\
\text { during time span }\end{array}$ & \\
\hline 8 & $\begin{array}{l}\text { Monitor operation of display } \\
\text { clock/date }\end{array}$ & $\begin{array}{l}\text { Verify system clock/date display } \\
\text { continue to operate and correctly } \\
\text { display time and date }\end{array}$ & \\
\hline 9 & Activate event & Verify Alarm received a OCS & \\
\hline 10 & Acknowledge Alarm & $\begin{array}{l}\text { Verify Alarm Acknowledged and } \\
\text { cleared }\end{array}$ & \\
\hline \multirow[t]{4}{*}{11} & \multirow[t]{4}{*}{$\begin{array}{l}\text { Verify date and time stamp of } \\
\text { event }\end{array}$} & $\begin{array}{l}\text { Verify Time Stamp in Message } \\
\text { History file of event }\end{array}$ & \\
\hline & & $\begin{array}{l}\text { Verify Time Stamp in Operator } \\
\text { Action file of event }\end{array}$ & \\
\hline & & $\begin{array}{l}\text { Verify Time Stamp in recent } \\
\text { alarm history window }\end{array}$ & \\
\hline & & $\begin{array}{l}\text { Verify Time Stamp in Alarm } \\
\text { History file. }\end{array}$ & \\
\hline 12 & \multicolumn{2}{|c|}{$\begin{array}{l}\text { Print the following files and verify correct time and date stamps. } \\
\text { TPSI file-/home/Date/Tpsi/W320.csv .. } \\
\text { Alarm history file - /home/Data/Message/AHF??????.Txt } \\
\text { Message history file - /home/Data/Message/DMF??????.Txt } \\
\text { Operator Action File - /home/Data/Message/opact.??????t } \\
\text { ASCII Historian file ---/home/Data/History/a_?????? (1 page) }\end{array}$} & \\
\hline
\end{tabular}


3.1.4 Test transition from February 29, 2000 11:55 PM to March 1, 2000 12:05 AM.

\begin{tabular}{|c|c|c|c|}
\hline step & Procedure & Expected output & Withess \\
\hline 1 & Power Down Master Station & Verify off condition & \\
\hline 2 & Power Up Master Station & $\begin{array}{l}\text { System will boot and bring } \\
\text { operating system on line. }\end{array}$ & \\
\hline 3 & $\begin{array}{l}\text { Logon as root and Set Station Date } \\
\text { to February } 29,200011: 55 \mathrm{PM}\end{array}$ & $\begin{array}{l}\text { Verify date/time entered as } \\
\text { specified }\end{array}$ & \\
\hline 4 & Logoff and Logon as Micon & $\begin{array}{l}\text { Verify display of basic Micon } \\
\text { screen, load monitor and proper } \\
\text { date/time clock display }\end{array}$ & \\
\hline 5 & $\begin{array}{l}\text { Perform Device Definition and } \\
\text { start AS/View }\end{array}$ & $\begin{array}{l}\text { Verify all controllers are on line } \\
\text { and existence of alarm panel in } \\
\text { lower screen. }\end{array}$ & \\
\hline 6 & Wait at least 10 minutes & No Action & \\
\hline 7 & $\begin{array}{l}\text { Monitor operation of Complete } \\
\text { System }\end{array}$ & $\begin{array}{l}\text { Verify system continued to work } \\
\text { during time span }\end{array}$ & \\
\hline 8 & $\begin{array}{l}\text { Monitor operation of display } \\
\text { clock/date }\end{array}$ & $\begin{array}{l}\text { Verify system clock/date display } \\
\text { continue to operate and correctly } \\
\text { display time and date }\end{array}$ & \\
\hline 9 & Activate event & Verify Alarm received a OCS & \\
\hline 10 & Acknowledge Alarm & $\begin{array}{l}\text { Verify Alarm Acknowledged anc } \\
\text { cleared }\end{array}$ & \\
\hline \multirow[t]{4}{*}{11} & \multirow[t]{4}{*}{$\begin{array}{l}\text { Verify date and time stamp of } \\
\text { event }\end{array}$} & $\begin{array}{l}\text { Verify Time Stamp in Message } \\
\text { History file of event }\end{array}$ & \\
\hline & & $\begin{array}{l}\text { Verify Time Stamp in Operator } \\
\text { Action file of event }\end{array}$ & \\
\hline & & $\begin{array}{l}\text { Verify Time Stamp in recent } \\
\text { alarm history window }\end{array}$ & \\
\hline & & $\begin{array}{l}\text { Verify Time Stamp in Alarm } \\
\text { History file. }\end{array}$ & \\
\hline 12 & \multicolumn{2}{|c|}{$\begin{array}{l}\text { Print the following files and verify correct time and date stamps. } \\
\text { TPSI file-/home/Date/Tpsi/W320.csv .. } \\
\text { Alarm history file - /home/Data/Message/AHF??????.Txt } \\
\text { Message history file - /home/Data/Message/DMF??????.Txt } \\
\text { Operator Action File - /home/Data/Message/opact.??????t } \\
\text { ASCII Historian file ---/home/Data/History/a_?????? (1 page) }\end{array}$} & \\
\hline
\end{tabular}


3.1.5 Test transition from December 30, 2000 11:55 PM to December 31, 2001 12:05 AM.

\begin{tabular}{|c|c|c|c|}
\hline step & Procedüre & Expected output & Witness \\
\hline 1 & Power Down Master Station & Verify off condition & \\
\hline 2 & Power Up Master Station & $\begin{array}{l}\text { System will boot and bring } \\
\text { operating system on line. }\end{array}$ & \\
\hline 3 & $\begin{array}{l}\text { Logon as root and Set Station } \\
\text { Date to December 30, } 2000 \text { 11:55 } \\
\text { PM }\end{array}$ & $\begin{array}{l}\text { Verify date/time entered as } \\
\text { specified }\end{array}$ & \\
\hline 4 & Logoff and Logon as Micon & $\begin{array}{l}\text { Verify display of basic Micon } \\
\text { screen, load monitor and } \\
\text { proper date/time clock display }\end{array}$ & \\
\hline 5 & $\begin{array}{l}\text { Perform Device Definition and } \\
\text { start AS/View }\end{array}$ & $\begin{array}{l}\text { Verify all controllers are on line } \\
\text { and existence of alarm panel in } \\
\text { lower screen. }\end{array}$ & \\
\hline 6 & Wait at least 10 minutes & No Action & \\
\hline 7 & $\begin{array}{l}\text { Monitor operation of Complete } \\
\text { System }\end{array}$ & $\begin{array}{l}\text { Verify system continued to } \\
\text { work during time span }\end{array}$ & \\
\hline 8 & $\begin{array}{l}\text { Monitor operation of display } \\
\text { clock/date }\end{array}$ & $\begin{array}{l}\text { Verify system clock/date } \\
\text { display continue to operate and } \\
\text { correctly display time and date }\end{array}$ & \\
\hline 9 & Activate event & Verify Alarm received a OCS & \\
\hline 10 & Acknowledge Alarm & $\begin{array}{l}\text { Verify Alarm Acknowledged } \\
\text { and cleared }\end{array}$ & \\
\hline \multirow[t]{4}{*}{11} & \multirow[t]{4}{*}{$\begin{array}{l}\text { Verify date and time stamp of } \\
\text { event }\end{array}$} & $\begin{array}{l}\text { Verify Time Stamp in Message } \\
\text { History file of event }\end{array}$ & \\
\hline & & $\begin{array}{l}\text { Verify Time Stamp in Operator } \\
\text { Action file of event }\end{array}$ & \\
\hline & & $\begin{array}{l}\text { Verify Time Stamp in recent } \\
\text { alarm history window }\end{array}$ & \\
\hline & & $\begin{array}{l}\text { Verify Time Stamp in Alarm } \\
\text { History file. }\end{array}$ & \\
\hline 12 & \multicolumn{2}{|c|}{$\begin{array}{l}\text { Print the following files and verify correct time and date stamps. } \\
\text { TPSI file-/home/Date/Tpsi/W320.csv .. } \\
\text { Alarm history file - /home/Data/Message/AHF??????.Txt } \\
\text { Message history file - /home/Data/Message/DMF??????.Txt } \\
\text { Operator Action File - /home/Data/Message/opact.??????t } \\
\text { ASCII Historian file --/ /home/Data/History/a_?????? (1 page) }\end{array}$} & \\
\hline
\end{tabular}


3.1.6 Test transition from December 31, 2000 11:55 PM to January 1, 2001 12:05 AM.

\begin{tabular}{|c|c|c|c|}
\hline step & Procedure & Expected output & Witness \\
\hline 1 & Power Down Master Station & Verify off condition & \\
\hline 2 & Power Up Master Station & $\begin{array}{l}\text { System will boot and bring } \\
\text { operating system on line. }\end{array}$ & \\
\hline 3 & $\begin{array}{l}\text { Logon as root and Set Station Date } \\
\text { to December } 31,200011: 55 \text { PM }\end{array}$ & $\begin{array}{l}\text { Verify date/time entered as } \\
\text { specified }\end{array}$ & \\
\hline 4 & Logoff and Logon as Micon & $\begin{array}{l}\text { Verify display of basic Micon } \\
\text { screen, load monitor and proper } \\
\text { date/time clock display }\end{array}$ & \\
\hline 5 & $\begin{array}{l}\text { Perform Device Definition and } \\
\text { start AS/View }\end{array}$ & $\begin{array}{l}\text { Verify all controllers are on line } \\
\text { and existence of alarm panel in } \\
\text { lower screen. }\end{array}$ & \\
\hline 6 & Wait at least 10 minutes & No Action & \\
\hline 7 & $\begin{array}{l}\text { Monitor operation of Complete } \\
\text { System }\end{array}$ & $\begin{array}{l}\text { Verify system continued to work } \\
\text { during time span }\end{array}$ & \\
\hline 8 & $\begin{array}{l}\text { Monitor operation of display } \\
\text { clock/date }\end{array}$ & $\begin{array}{l}\text { Verify system clock/date display } \\
\text { continue to operate and correctly } \\
\text { display time and date }\end{array}$ & \\
\hline 9 & Activate event & Verify Alarm received a OCS & \\
\hline 10 & Acknowledge Alarm & $\begin{array}{l}\text { Verify Alarm Acknowledged and } \\
\text { cleared }\end{array}$ & \\
\hline \multirow[t]{4}{*}{11} & \multirow[t]{4}{*}{$\begin{array}{l}\text { Verify date and time stamp of } \\
\text { event }\end{array}$} & $\begin{array}{l}\text { Verify Time Stamp in Message } \\
\text { History file of event }\end{array}$ & \\
\hline & & $\begin{array}{l}\text { Verify Time Stamp in Operator } \\
\text { Action file of event }\end{array}$ & \\
\hline & & $\begin{array}{l}\text { Verify Time Stamp in recent } \\
\text { alarm history window }\end{array}$ & \\
\hline & & $\begin{array}{l}\text { Verify Time Stamp in Alarm } \\
\text { History file. }\end{array}$ & \\
\hline 12 & \multicolumn{2}{|c|}{$\begin{array}{l}\text { Print the following files and verify correct time and date stamps. } \\
\text { TPSI file-/home/Date/Tpsi/W320.csv .. } \\
\text { Alarm history file - /home/Data/Message/AHF?????? Txt } \\
\text { Message history file - /home/Data/Message/DMF??????.Txt } \\
\text { Operator Action File - /home/Data/Message/opact.??????t } \\
\text { ASCII Historian file ---/home/Data/History/a_?????? (1 page) }\end{array}$} & \\
\hline
\end{tabular}


3.1.7 Test transition from February 28, 2001 11:55 PM to March 1, 2001 12:05 AM.

\begin{tabular}{|c|c|c|c|}
\hline step & Procedure & Expected output & Witness \\
\hline 1 & Power Down Master Station & Verify off condition & \\
\hline 2 & Power Up Master Station & $\begin{array}{l}\text { System will boot and bring } \\
\text { operating system on line. }\end{array}$ & \\
\hline 3 & $\begin{array}{l}\text { Logon as root and Set Station Date } \\
\text { to February } 28,200111: 55 \mathrm{PM}\end{array}$ & $\begin{array}{l}\text { Verify date/time entered as } \\
\text { specified }\end{array}$ & \\
\hline 4 & Logoff and Logon as Micon & $\begin{array}{l}\text { Verify display of basic Micon } \\
\text { screen, load monitor and proper } \\
\text { date/time clock display }\end{array}$ & \\
\hline 5 & $\begin{array}{l}\text { Perform Device Definition and } \\
\text { start AS/View }\end{array}$ & $\begin{array}{l}\text { Verify all controllers are on line } \\
\text { and existence of alarm panel in } \\
\text { lower screen. }\end{array}$ & \\
\hline 6 & Wait at least 10 minutes & No Action & \\
\hline 7 & $\begin{array}{l}\text { Monitor operation of Complete } \\
\text { System }\end{array}$ & $\begin{array}{l}\text { Verify system continued to work } \\
\text { during time span }\end{array}$ & \\
\hline 8 & $\begin{array}{l}\text { Monitor operation of display } \\
\text { clock/date }\end{array}$ & $\begin{array}{l}\text { Verity system clock/date display } \\
\text { continue to operate and correctly } \\
\text { display time and date }\end{array}$ & \\
\hline 9 & Activate event & Verify Alarm received a OCS & \\
\hline 10 & Acknowledge Alarm & $\begin{array}{l}\text { Verify Alarm Acknowledged anc } \\
\text { cleared }\end{array}$ & \\
\hline \multirow[t]{4}{*}{11} & \multirow[t]{4}{*}{$\begin{array}{l}\text { Verify date and time stamp of } \\
\text { event }\end{array}$} & $\begin{array}{l}\text { Verify Time Stamp in Message } \\
\text { History file of event }\end{array}$ & \\
\hline & & $\begin{array}{l}\text { Verify Time Stamp in Operator } \\
\text { Action file of event }\end{array}$ & \\
\hline & & $\begin{array}{l}\text { Verify Time Stamp in recent } \\
\text { alarm history window }\end{array}$ & \\
\hline & & $\begin{array}{l}\text { Verify Time Stamp in Alarm } \\
\text { History file. }\end{array}$ & \\
\hline 12 & \multicolumn{2}{|c|}{$\begin{array}{l}\text { Print the following files and verify correct time and date stamps. } \\
\text { TPSI file-/home/Date/Tpsi/ W320.csv .. } \\
\text { Alarm history file - /home/Data/Message/AHF??????.Txt } \\
\text { Message history file - /home/Data/Message/DMF??????.Txt } \\
\text { Operator Action File - /home/Data/Message/opact.??????t } \\
\text { ASCII Historian file ---/home/Data/History/a_?????? (1 page) }\end{array}$} & \\
\hline
\end{tabular}




\subsubsection{Return System to current Time and Date.}

\begin{tabular}{|c|c|c|c|}
\hline step. & Procedure & Expected oufput & Witness \\
\hline 1 & Power Down Master Station & Verify off condition & \\
\hline 2 & Power Up Master Station & $\begin{array}{l}\text { System will boot and bring } \\
\text { operating system on line. }\end{array}$ & \\
\hline 3 & $\begin{array}{l}\text { Logon as root and Set Station Date } \\
\text { to Current. }\end{array}$ & $\begin{array}{l}\text { Verify date/time entered as } \\
\text { specified }\end{array}$ & \\
\hline 4 & Logoff and Logon as Micon & $\begin{array}{l}\text { Verify display of basic Micon } \\
\text { screen, load monitor and proper } \\
\text { date/time clock display }\end{array}$ & \\
\hline 5 & $\begin{array}{l}\text { Perform Device Definition and } \\
\text { start AS/View }\end{array}$ & $\begin{array}{l}\text { Verify all controllers are on line } \\
\text { and existence of alarm panel in } \\
\text { lower screen. }\end{array}$ & \\
\hline 6 & Wait 15 minutes & No Action & \\
\hline 7 & $\begin{array}{l}\text { Monitor operation of Complete } \\
\text { System }\end{array}$ & $\begin{array}{l}\text { Verify system continued to work } \\
\text { during time span }\end{array}$ & \\
\hline 8 & $\begin{array}{l}\text { Monitor operation of display } \\
\text { clock/date }\end{array}$ & $\begin{array}{l}\text { Verity system clock/date display } \\
\text { continue to operate and correctly } \\
\text { display time and date }\end{array}$ & \\
\hline 9 & Activate event & Verify Alarm received a OCS & \\
\hline 10 & Acknowledge Alarm & $\begin{array}{l}\text { Verify Alarm Acknowledged anc } \\
\text { cleared }\end{array}$ & \\
\hline \multirow[t]{4}{*}{11} & \multirow[t]{4}{*}{$\begin{array}{l}\text { Verify date and time stamp of } \\
\text { event }\end{array}$} & $\begin{array}{l}\text { Verify Time Stamp in Message } \\
\text { History file of event }\end{array}$ & \\
\hline & & $\begin{array}{l}\text { Verify Time Stamp in Operator } \\
\text { Action file of event }\end{array}$ & \\
\hline & & $\begin{array}{l}\text { Verify Time Stamp in recent } \\
\text { alarm history window }\end{array}$ & \\
\hline & & $\begin{array}{l}\text { Verify Time Stamp in Alarm } \\
\text { History file. }\end{array}$ & \\
\hline 12 & \multicolumn{2}{|c|}{$\begin{array}{l}\text { Print the following files and verify correct time and date stamps. } \\
\text { TPSI file-/home/Date/Tpsi/ W320.csv .. } \\
\text { Alarm history file - /home/Data/Message/AHF??????.Txt } \\
\text { Message history file - /home/Data/Message/DMF?????.Txt } \\
\text { Operator Action File - /home/Data/Message/opact.??????t } \\
\text { ASCII Historian file ---/home/Data/History/a ?????? (1 page) }\end{array}$} & \\
\hline
\end{tabular}




\subsection{Fire Control Station Simplex Time Recording Co. Model 4100-8001.}

The 702AZ Ventilation Facility Fire Control system is made by Simplex Time Recording Co. A year 2000 compliance statement is provided on the Internet at http://www.simplexnet.com/products/Y2KFire.htm. There is no date related functionality in this system and it therefore does not need to be tested.

Simplex provides the following statement in regards to the model 4001 Year 2000 compatibility.

"The processor's used in these panels have on board timers that measure elapsed time in the micro or milli second range. Via software these timers can be used to implement date functions, if required. These panels do not support date functionality and none is implemented in them, therefore they are not sensitive to year 2000.

Simplex is making every effort to provide accurate and up-to-date information on the Year 2000 readiness of its products. The information in the Simplex Home Page reflects the current results of compliance tests and may be updated or changed without notice as testing continues. This information is published for your assistance only. An overall Year 2000 assessment and plan based on your particular needs is your responsibility.

Simplex disclaims the implied warranties of merchantability and fitness for a particular purpose and makes no express warranties except as may be stated in its written agreement with its customers. In no event is Simplex liable to anyone for any indirect, special or consequential damages."

Because the Fire Alarm system is not part of the Ventilation Process system and it provides no date related functionalityk, it will not be formally tested. 
3.2 Fire Control Station Simplex Time Recording Co. Model 4100-8001.

The 702AZ Ventilation Facility Fire Control system is made by Simplex Time Recording Co. A year 2000 compliance statement is provided on the Internet at http://www.simplexnet.com/products/Y2KFire.htm. There is no date related functionality in this system and it therefore does not need to be tested.

Simplex provides the following statement in regards to the model 4001 Year 2000 compatibility.

"The processor's used in these panels have on board timers that measure elapsed time in the micro or milli second range. Via software these timers can be used to implement date functions, if required. These panels do not support date functionality and none is implemented in them, therefore they are not sensitive to year 2000.

Simplex is making every effort to provide accurate and up-to-date information on the Year 2000 readiness of its products. The information in the Simplex Home Page reflects the current results of compliance tests and may be updated or changed without notice as testing continues. This information is published for your assistance only. An overall Year 2000 assessment and plan based on your particular needs is your responsibility.

Simplex disclaims the implied warranties of merchantability and fitness for a particular purpose and makes no express warranties except as may be stated in its written agreement with its customers. In no event is Simplex liable to anyone for any indirect, special or consequential damages."

Because the Fire Alarm system is not part of the Ventilation Process system and it provides no date related functionality, it will not be formally tested. 


\subsection{Control Room Air Conditioner DA Data Aire Inc. DTAU-0332}

The control room air conditioner provides heating/cooling and humidity control for the Control room building. There is only one of these systems. The system will not be shut down after each section of the test. The ability of the system to restart at the correct time is unimportant.

\begin{tabular}{|l|l|l|l|}
\hline Step & Procedure & Witness \\
\hline 1 & $\begin{array}{l}\text { Enter authorization password and } \\
\text { set Time and Date to December } \\
31,199911: 55 \text { PM }\end{array}$ & $\begin{array}{l}\text { Verify date/time entered as } \\
\text { specified }\end{array}$ & \\
\hline 2 & Wait at least 10 minutes & No Action & \\
\hline 3 & Monitor operation of System & $\begin{array}{l}\text { Verify system continued to work } \\
\text { during time span }\end{array}$ & \\
\hline 4 & $\begin{array}{l}\text { Enter authorization password and } \\
\text { set Time and Date to February } 28, \\
200011: 55 \text { PM }\end{array}$ & $\begin{array}{l}\text { Verify date/time entered as } \\
\text { specified }\end{array}$ & \\
\hline 5 & Wait at least 10 minutes & No Action \\
\hline 6 & Monitor operation of System & $\begin{array}{l}\text { Verify system continued to work } \\
\text { during time span }\end{array}$ & \\
\hline 7 & $\begin{array}{l}\text { Logon as root and Set Station Date } \\
\text { to February } 29,200011: 55 \text { PM }\end{array}$ & $\begin{array}{l}\text { Verify date/time entered as } \\
\text { specified }\end{array}$ & \\
\hline 8 & Wait at least 10 minutes & No Action & \\
\hline 9 & Monitor operation of System & $\begin{array}{l}\text { Verify system continued to work } \\
\text { during time span }\end{array}$ & \\
\hline 10 & $\begin{array}{l}\text { Enter authorization password and } \\
\text { set Time and Date to December } \\
30,200011: 55 \text { PM }\end{array}$ & $\begin{array}{l}\text { Verify date/time entered as } \\
\text { specified }\end{array}$ & \\
\hline 11 & Wait at least 10 minutes & No Action & \\
\hline 12 & Monitor operation of System & $\begin{array}{l}\text { Verify system continued to work } \\
\text { during time span }\end{array}$ & \\
\hline 13 & $\begin{array}{l}\text { Enter authorization password and } \\
\text { set Time and Date to December } \\
31,200011: 55 \text { PM }\end{array}$ & $\begin{array}{l}\text { Verify date/time entered as } \\
\text { specified }\end{array}$ & \\
\hline 14 & Wait at least 10 minutes & No Action \\
\hline 15 & Monitor operation of System & $\begin{array}{l}\text { Verify system continued to work } \\
\text { during time span }\end{array}$ & \\
\hline 16 & $\begin{array}{l}\text { Enter authorization password and } \\
\text { set Time and Date to February } 28, \\
200111: 55 \text { PM }\end{array}$ & $\begin{array}{l}\text { Verify date/time entered as } \\
\text { specified }\end{array}$ & No Action \\
\hline 17 & Wait at least 10 minutes & $\begin{array}{l}\text { Verify system continued to work } \\
\text { during time span }\end{array}$ & \\
\hline 18 & Monitor operation of System & Verify system continues to work & \\
\hline 19 & $\begin{array}{l}\text { Enter authorization password and } \\
\text { set Time and Date to current }\end{array}$ & \\
\hline
\end{tabular}




\subsection{Primary Process Air Chiller Dunham Bush model ACDR-55-B}

The primary process Air Chiller provides cooling to the main process air stream. There is only one chiller in the system and although important, the process can be run without it. The chiller will not be shut down between testing each time since the ability to restart at the correct time is unimportant.

\begin{tabular}{|c|c|c|c|}
\hline step & ख ४ै। & Expected output & Witress \\
\hline 1 & $\begin{array}{l}\text { Enter authorization password and } \\
\text { set Time and Date to December } \\
31,1999 \text { 11:55 PM }\end{array}$ & $\begin{array}{l}\text { Verify date/time entered as } \\
\text { specified }\end{array}$ & \\
\hline 2 & Wait at least 10 minutes & No Action & \\
\hline$\overline{3}$ & Monitor operation of System & $\begin{array}{l}\text { Verify system continued to work } \\
\text { during time span }\end{array}$ & \\
\hline 4 & $\begin{array}{l}\text { Enter authorization password and } \\
\text { set Time and Date to February 28, } \\
200011: 55 \text { PM }\end{array}$ & $\begin{array}{l}\text { Verify date/time entered as } \\
\text { specified }\end{array}$ & \\
\hline 5 & Wait at least 10 minutes & No Action & \\
\hline 6 & Monitor operation of System & $\begin{array}{l}\text { Verify system continued to work } \\
\text { during time span }\end{array}$ & \\
\hline 7 & $\begin{array}{l}\text { Logon as root and Set Station Date } \\
\text { to February } 29,200011: 55 \text { PM }\end{array}$ & $\begin{array}{l}\text { Verify date/time entered as } \\
\text { specified }\end{array}$ & \\
\hline 8 & Wait at least 10 minutes & No Action & \\
\hline 9 & Monitor operation of System & $\begin{array}{l}\text { Verify system continued to work } \\
\text { during time span }\end{array}$ & \\
\hline 10 & $\begin{array}{l}\text { Enter authorization password and } \\
\text { set Time and Date to December } \\
\text { 30, 2000 11:55 PM }\end{array}$ & $\begin{array}{l}\text { Verify date/time entered as } \\
\text { specified }\end{array}$ & \\
\hline 11 & Wait at least 10 minutes & No Action & \\
\hline 12 & Monitor operation of System & $\begin{array}{l}\text { Verify system continued to work } \\
\text { during time span }\end{array}$ & \\
\hline 13 & $\begin{array}{l}\text { Enter authorization password and } \\
\text { set Time and Date to December } \\
\text { 31, 2000 11:55 PM }\end{array}$ & $\begin{array}{l}\text { Verify date/time entered as } \\
\text { specified }\end{array}$ & \\
\hline 14 & Wait at least 10 minutes & No Action & \\
\hline 15 & Monitor operation of System & $\begin{array}{l}\text { Verify system continued to work } \\
\text { during time span }\end{array}$ & \\
\hline 16 & $\begin{array}{l}\text { Enter authorization password and } \\
\text { set Time and Date to February 28, } \\
200111: 55 \text { PM }\end{array}$ & $\begin{array}{l}\text { Verify date/time entered as } \\
\text { specified }\end{array}$ & \\
\hline 17 & Wait at least 10 minutes & No Action & \\
\hline 18 & Monitor operation of System & $\begin{array}{l}\text { Verify system continued to work } \\
\text { during time span }\end{array}$ & \\
\hline
\end{tabular}


HNF-2981 Rev. 0

\begin{tabular}{|l|l|l}
\hline 19 & Enter authorization password and & Verify system continues to work
\end{tabular} set Time and Date to current 


\subsection{Continuous Air Monitor Eberline model AMS-4 Software version 3.0}

The Continuous Air Monitor provides real time monitoring of stack radioactive particulates. There are two CAMS in the system. One CAM monitors the building stack and one monitors the primary process stack. Testing will be performed on the Spare CAM which is identical to the other two. Verification that each CAM is operating with V 3.0 firmware will be performed.

\begin{tabular}{|c|c|c|c|}
\hline step & Procedure & Expected output & Witness \\
\hline 1 & Power Down CAM & Verify off condition & \\
\hline 2 & Power UP CAM & $\begin{array}{l}\text { Verify correct date, time and } \\
\text { operation of system. }\end{array}$ & \\
\hline 3 & $\begin{array}{l}\text { Enter authorization password } \\
\text { and set Time and Date to } \\
\text { December } 31,199911: 55 \text { PM }\end{array}$ & $\begin{array}{l}\text { Verify date/time entered as } \\
\text { specified }\end{array}$ & \\
\hline 4 & Wait at least 10 minutes & No Action & \\
\hline 5 & Monitor operation of System & $\begin{array}{l}\text { Verify system continued to work } \\
\text { during time span }\end{array}$ & \\
\hline 6 & Power Down CAM & Verify off condition & \\
\hline 7 & Power UP CAM & $\begin{array}{l}\text { Verify correct date, time and } \\
\text { operation of system. }\end{array}$ & \\
\hline 8 & $\begin{array}{l}\text { Enter authorization password } \\
\text { and set Time and Date to } \\
\text { February } 28,200011: 55 \mathrm{PM}\end{array}$ & $\begin{array}{l}\text { Verify date/time entered as } \\
\text { specified }\end{array}$ & \\
\hline 9 & Wait at least 10 minutes & No Action & \\
\hline 10 & Monitor operation of System & $\begin{array}{l}\text { Verify system continued to work } \\
\text { during time span }\end{array}$ & \\
\hline 11 & Power Down CAM & Verify off condition & \\
\hline 12 & Power UP CAM & $\begin{array}{l}\text { Verify correct date, time and } \\
\text { operation of system. }\end{array}$ & \\
\hline 13 & $\begin{array}{l}\text { Logon as root and Set Station } \\
\text { Date to February 29, } 200011: 55 \\
\text { PM }\end{array}$ & $\begin{array}{l}\text { Verify date/time entered as } \\
\text { specified }\end{array}$ & \\
\hline 14 & Wait at least 10 minutes & No Action & \\
\hline$\overline{15}$ & Monitor operation of System & $\begin{array}{l}\text { Verify system continued to work } \\
\text { during time span }\end{array}$ & \\
\hline 16 & Power Down CAM & Verify off condition & \\
\hline 17 & Power UP CAM & $\begin{array}{l}\text { Verify correct date, time and } \\
\text { operation of system. }\end{array}$ & \\
\hline 18 & $\begin{array}{l}\text { Enter authorization password } \\
\text { and set Time and Date to } \\
\text { December } 30,200011: 55 \mathrm{PM}\end{array}$ & $\begin{array}{l}\text { Verify date/time entered as } \\
\text { specified }\end{array}$ & \\
\hline 19 & Wait at least 10 minutes & No Action & \\
\hline
\end{tabular}


HNF-2981 Rev. 0

\begin{tabular}{|l|l|l|l|}
\hline Step & Proceduire & Wexpected output & Vitiess \\
\hline 20 & Monitor operation of System & $\begin{array}{l}\text { Verify system continued to work } \\
\text { during time span }\end{array}$ & \\
\hline 21 & $\begin{array}{l}\text { Enter authorization password } \\
\text { and set Time and Date to } \\
\text { December } 31,200011: 55 \text { PM }\end{array}$ & $\begin{array}{l}\text { Verify date/time entered as } \\
\text { specified }\end{array}$ & \\
\hline 22 & Wait at least 10 minutes & No Action & \\
\hline 23 & Monitor operation of System & $\begin{array}{l}\text { Verify system continued to work } \\
\text { during time span }\end{array}$ & \\
\hline 24 & Power Down CAM & Verify off condition & \\
\hline 25 & Power UP CAM & $\begin{array}{l}\text { Verify correct date, time and } \\
\text { operation of system. }\end{array}$ & \\
\hline 26 & $\begin{array}{l}\text { Enter authorization password } \\
\text { and set Time and Date to } \\
\text { February } 28,200111: 55 \text { PM }\end{array}$ & $\begin{array}{l}\text { Verify date/time entered as } \\
\text { specified }\end{array}$ & \\
\hline 27 & Wait at least 10 minutes & No Action & $\begin{array}{l}\text { Verify system continued to work } \\
\text { during time span }\end{array}$ \\
\hline 28 & Monitor operation of System & Verify off condition & \\
\hline 29 & Power Down CAM & $\begin{array}{l}\text { Verify correct date, time and } \\
\text { operation of system. }\end{array}$ & \\
\hline 30 & Power UP CAM & Verify system continues to work & \\
\hline 31 & $\begin{array}{l}\text { Enter authorization password } \\
\text { and set Time and Date to current }\end{array}$ & \\
\hline
\end{tabular}




\subsection{Variable Speed Drive Cutler Hammer Model AF95}

The Variable Speed Drive is used to adjust fan speed and control the pressure and thus the flow of the Ventilation system. Their are two Variable Speed Drives. One for each of the System Fans. The tests will only be run on one of the VSD's in that they are identical. The test will be run on the off line VSD and not the one currently providing flow for the process.

\begin{tabular}{|c|c|c|c|}
\hline step & Procedure & Expected oufpirt & Witness \\
\hline 1 & Power Down VSD & Verify off condition & \\
\hline 2 & Power UP VSD & $\begin{array}{l}\text { Verify correct date, time and } \\
\text { operation of system. }\end{array}$ & \\
\hline 3 & $\begin{array}{l}\text { Enter authorization password and } \\
\text { set Time and Date to December } \\
31,199911: 55 \text { PM }\end{array}$ & $\begin{array}{l}\text { Verify date/time entered as } \\
\text { specified }\end{array}$ & \\
\hline 4 & Wait at least 10 minutes & No Action & \\
\hline 5 & Monitor operation of System & $\begin{array}{l}\text { Verify system continued to work } \\
\text { during time span }\end{array}$ & \\
\hline 6 & Power Down VSD & Verify off condition & \\
\hline 7 & Power UP VSD & $\begin{array}{l}\text { Verify correct date, time and } \\
\text { operation of system. }\end{array}$ & \\
\hline 8 & $\begin{array}{l}\text { Enter authorization password and } \\
\text { set Time and Date to February } 28 \text {, } \\
200011: 55 \text { PM }\end{array}$ & $\begin{array}{l}\text { Verify date/time entered as } \\
\text { specified }\end{array}$ & \\
\hline 9 & Wait at least 10 minutes & No Action & \\
\hline 10 & Monitor operation of System & $\begin{array}{l}\text { Verify system continued to work } \\
\text { during time span }\end{array}$ & \\
\hline 11 & Power Down VSD & Verify off condition & \\
\hline 12 & Power UP VSD & $\begin{array}{l}\text { Verify correct date, time and } \\
\text { operation of system. }\end{array}$ & \\
\hline 13 & $\begin{array}{l}\text { Logon as root and Set Station } \\
\text { Date to February } 29,200011: 55 \\
\text { PM }\end{array}$ & $\begin{array}{l}\text { Verify date/time entered as } \\
\text { specified }\end{array}$ & \\
\hline 14 & Wait at least 10 minutes & No Action & \\
\hline 15 & Monitor operation of System & $\begin{array}{l}\text { Verify system continued to work } \\
\text { during time span }\end{array}$ & \\
\hline 16 & Power Down VSD & Verify off condition & \\
\hline 17 & Power UP VSD & $\begin{array}{l}\text { Verify correct date, time and } \\
\text { operation of system. }\end{array}$ & \\
\hline 18 & $\begin{array}{l}\text { Enter authorization password and } \\
\text { set Time and Date to December } \\
\text { 30,2000 11:55 PM }\end{array}$ & $\begin{array}{l}\text { Verify date/time entered as } \\
\text { specified }\end{array}$ & \\
\hline 19 & Wait at least 10 minutes & No Action & \\
\hline 20 & Monitor operation of System & $\begin{array}{l}\text { Verify system continued to work } \\
\text { during time span }\end{array}$ & \\
\hline
\end{tabular}


HNF-2981 Rev. 0

\begin{tabular}{|l|l|l|l|}
\hline step & Procedure & Witaess \\
\hline 21 & Power Down VSD & Verify off condition & \\
\hline 22 & Power UP VSD & $\begin{array}{l}\text { Verify correct date, time and } \\
\text { operation of system. }\end{array}$ & \\
\hline 23 & $\begin{array}{l}\text { Enter authorization password and } \\
\text { set Time and Date to December } \\
31,200011: 55 \text { PM }\end{array}$ & $\begin{array}{l}\text { Verify date/time entered as } \\
\text { specified }\end{array}$ & \\
\hline 24 & Wait at least 10 minutes & No Action & \\
\hline 25 & Monitor operation of System & $\begin{array}{l}\text { Verify system continued to work } \\
\text { during time span }\end{array}$ & \\
\hline 26 & Power Down VSD & Verify off condition & \\
\hline 27 & Power UP VSD & $\begin{array}{l}\text { Verify correct date, time and } \\
\text { operation of system. }\end{array}$ & \\
\hline 28 & $\begin{array}{l}\text { Enter authorization password and } \\
\text { set Time and Date to February } 28, \\
200111: 55 \text { PM }\end{array}$ & $\begin{array}{l}\text { Verify date/time entered as } \\
\text { specified }\end{array}$ & \\
\hline 29 & Wait at least 10 minutes & No Action & \\
\hline 30 & Monitor operation of System & $\begin{array}{l}\text { Verify system continued to work } \\
\text { during time span }\end{array}$ & \\
\hline 31 & Power Down VSD & Verify off condition & \\
\hline 32 & Power UP VSD & $\begin{array}{l}\text { Verify correct date, time and } \\
\text { operation of system. }\end{array}$ & \\
\hline 33 & $\begin{array}{l}\text { Enter authorization password and } \\
\text { set Time and Date to current }\end{array}$ & \begin{tabular}{l} 
Verify system continues to work \\
\hline
\end{tabular} &
\end{tabular}




\subsection{Un-interruptable Power Supply International Power Machines Model IBP+10}

The Un-interruptable Power Supply provides power to loads which need to remain powered during the transition to backup power upon a loss of facility power. There are three identical UPS's. Only one UPS will be tested. Select the UPS associated with the Ventilation train which is currently in standby. The UPS should be placed in bypass before testing. Since the UPS has its own backup power, powering down the UPS between test phases is not required.

\begin{tabular}{|c|c|c|c|}
\hline step & Procedure & Expected output & Witness \\
\hline 1 & $\begin{array}{l}\text { Enter authorization password and } \\
\text { set Time and Date to December } \\
31,1999 \text { 11:55 PM }\end{array}$ & $\begin{array}{l}\text { Verify date/time entered as } \\
\text { specified }\end{array}$ & \\
\hline 2 & Wait at least 10 minutes & No Action & \\
\hline 3 & Monitor operation of System & $\begin{array}{l}\text { Verify system continued to work } \\
\text { during time span }\end{array}$ & \\
\hline 4 & $\begin{array}{l}\text { Enter authorization password and } \\
\text { set Time and Date to February 28, } \\
2000 \text { 11:55 PM }\end{array}$ & $\begin{array}{l}\text { Verify date/time entered as } \\
\text { specified }\end{array}$ & \\
\hline 5 & Wait at least 10 minutes & No Action & \\
\hline 6 & Monitor operation of System & $\begin{array}{l}\text { Verify system continued to work } \\
\text { during time span }\end{array}$ & \\
\hline 7 & $\begin{array}{l}\text { Logon as root and Set Station Date } \\
\text { to February } 29,200011: 55 \mathrm{PM}\end{array}$ & $\begin{array}{l}\text { Verify date/time entered as } \\
\text { specified }\end{array}$ & \\
\hline 8 & Wait at least 10 minutes & No Action & \\
\hline 9 & Monitor operation of System & $\begin{array}{l}\text { Verify system continued to work } \\
\text { during time span }\end{array}$ & \\
\hline 10 & $\begin{array}{l}\text { Enter authorization password and } \\
\text { set Time and Date to December } \\
\text { 30, } 2000 \text { 11:55 PM }\end{array}$ & $\begin{array}{l}\text { Verify date/time entered as } \\
\text { specified }\end{array}$ & \\
\hline 11 & Wait at least 10 minutes & No Action & \\
\hline 12 & Monitor operation of System & $\begin{array}{l}\text { Verify system continued to work } \\
\text { during time span. }\end{array}$ & \\
\hline 13 & $\begin{array}{l}\text { Enter authorization password and } \\
\text { set Time and Date to December } \\
31,200011: 55 \text { PM }\end{array}$ & $\begin{array}{l}\text { Verify date/time entered as } \\
\text { specified }\end{array}$ & \\
\hline 14 & Wait at least 10 minutes & No Action & \\
\hline 15 & Monitor operation of System & $\begin{array}{l}\text { Verify system continued to work } \\
\text { during time span }\end{array}$ & \\
\hline 16 & $\begin{array}{l}\text { Enter authorization password and } \\
\text { set Time and Date to February 28, } \\
2001 \text { 11:55 PM }\end{array}$ & $\begin{array}{l}\text { Verify date/time entered as } \\
\text { specified }\end{array}$ & \\
\hline
\end{tabular}


HNF-2981 Rev. 0

\begin{tabular}{|l|l|l|l|}
\hline step & Procedure & Expected output & Witness \\
\hline 17 & Wait at least 10 minutes & No Action & \\
\hline 18 & Monitor operation of System & $\begin{array}{l}\text { Verify system continued to work } \\
\text { during time span }\end{array}$ & \\
\hline 19 & $\begin{array}{l}\text { Enter authorization password and } \\
\text { set Time and Date to current }\end{array}$ & Verify system continues to work & \\
\hline
\end{tabular}




\title{
ATTACHMENT 1: 702AZ VENTILATION FACILITY YEAR 2000 TEST CRITERIA
}

Y2K Program Critical Dates and Justification of exceptions to testing

\author{
CURRRENT DATE AND TIME Will be tested \\ 9/30/1998-10/1/1998 --(Tests FY 1999) Not tested. Application does not use FY. \\ 9/8/1998 to $9 / 9 / 1999$-- (Tests 9999 ) \\ $12 / 31 / 1999$ to $1 / 1 / 2000$--- (Change of millennium) Will be tested \\ 9/30/99 to 10/1/1999 (Tests FY2000)Not tested. Application does not use FY. \\ $2 / 28 / 2000$ to $2 / 29 / 2000$ ( Recognition of leap year) Will be tested \\ $2 / 29 / 2000$ to $3 / 1 / 2000$ (Does not go to Feb. 30 or 31st) Will be tested \\ $2 / 20 / 2001$ (should create error) Not tested. Testing for all data entry errors is not \\ imporatant. \\ 9/30/2000 to 10/1/2000 (tests FY 2001)Not tested. Application does not use FY. \\ $12 / 30 / 2000$ to $12 / 31 / 2000$ (Checks for bad leap year calculation)Will be tested \\ $12 / 31 / 2000$ to $1 / 1 / 2001$ (Tests leap year 366 days) Will be tested \\ $2 / 28 / 2001$ to $3 / 1 / 2001$ (tests for none leap year) Will be tested
}

\section{Criteria:}

All systems transition to the tested critical dates without failures.

Micon clock transitions to the correct time and date at the above stated critical dates.

Micon file save dates just after time transitions to critical dates are correct.

Data Message files and Alarm History Files are properly issued on critical dates.

The date and time stamps are correct in the Recent Alarms Window and on the various alarm summaries.

Both the pictorial Historian and ASCII Historian are operational on all dates tested.

The ASCII historian data is correctly time and date stamped.

The Pictorial Historian properly depicts the correct time stamp when selecting a point from the live display.

The Third Party Report program will update files on the tested dates.

The Third Party Report program correctly time and date stamps data within the resultant text files. 
HNF-2981 Rev. 0

ATTACHMENT 2: TEST DISCREPANCY LOG SHEET

Page

of

STEP

STEP

NUMBER

DESCRIPTION

RESOLUTION

CLOSED

DATE 